\title{
Another third way? VW and the trials of stakeholder capitalism
}

\author{
Ian Clark
}

\begin{abstract}
The continuing crisis at Volkswagen has attracted widespread attention and concern in its seeming epitomisation of the 'sclerosis' of the German business system and Germany's system of industrial relations in large firms. These wider, systemic questions are reviewed here as well as the key, related issue as to how far, under globalisation, German corporate success can be achieved while retaining its long-established approach towards social cohesion.
\end{abstract}

\section{INTRODUCTION}

For Chancellor Merkel and many in the German business class, the ongoing crisis at Volkswagen (VW) epitomises a wider sclerosis suffered by the German business system and within this its system of industrial relations in large firms. VW's Wolfsburg plant is so overmanned that natural wastage must account for 5,000 redundancies per year for the foreseeable future and VW's largest shareholder-Lower Saxony-is frequently charged with letting the workforce run the company to the extent that today manufacturing costs in the plant are 40 per cent greater than those of VW's competitors. Further, even if Wolfgang Bernhard, Head of the VW brand, is successful in achieving a 30 per cent reduction in labour costs by 2008 , VW may well remain less productive than its competitors. Beyond VW, the German government appears impotent in the face of deeper Europeanisation and is only capable of limiting recession by breaching EU Stability and Growth Pact conditions on annual public debt at 3 per cent of national income and, even then, unemployment remains at 5 million and accumulated public debt a massive 66 per cent of GDP.

In reviewing developments in the German business system over the past year or so, this article seeks to raise three issues for discussion. First, what does the crisis at VW tell us about any wider crisis in the German business system and its attendant industrial relations system? Second, how does the literature make sense of what is going on in the business system and industrial relations system? Third, what are the industrial relations implications of evidently divergent responses to pressures for movement towards shareholder capitalism in the German economy? The key issue surrounding

$\square$ Ian Clark is Senior Lecturer in International Management and Organisation Research, Birmingham Business School, and Book Reviews Editor for the Industrial Relations Journal. Correspondence should be addressed to Dr Ian Clark, Birmingham Business School, University of Birmingham, Edgbaston, Birmingham B15 2TT, UK; email: clarkia@adf.bham.ac.uk 
these three questions centres on the potential for a decoupling of corporate success and broader measures of social cohesion in the German economy and under the pressures of globalisation.

\section{CORRUPTION, OVERMANNING AND TRADING DOWN: CRISIS AT VW?}

Created by Hitler in the 1930s, renewed and protected by the occupying powers under the Marshall Plan and the European Recovery Programme, VW, like the social market economy, epitomised postwar economic revival and sustained success in the German business system. However, the early 1990 s witnessed a major shock as globalisation exposed VW's comparatively high costs and overcapacity in production when renewed competitive pressures from within and beyond the EU and the USA saw declining sales of VW group cars. In early 2006, VW announced plans to restructure the firm in an effort to raise labour productivity, cut costs, reform workplace industrial relations and reduce overcapacity in production (Milne, 2006). In combination, these strategies are designed to save $€ 7$ billion and increase productivity by 30 per cent by 2010. With greater use of common components across models, VW announced that Toyota and not Mercedes would be the firm's main competitor, wherein the aim is to produce each model more cheaply than the previous one. Movement towards volume production is in marked contrast to VW's reaction to crisis in the 1970 s, when in the face of emerging competition from Japanese producers, VW like other German car producers did cut back on labour but moved production upmarket towards higher value added, by improving design, quality and product range to focus on the European market (O’Sullivan, 2000: 250-251; Streeck, 1989). As Streeck (1984) demonstrates, VW was able to achieve these changes in large measure because of its conservative and cooperative works council. In addition to this, VW was able to rely on rural migrants and guest workers who were prepared to accept whatever working conditions were on offer to underpin their comparatively very high wage levels (Bardou et al., 1982: 247-249). In the contemporary period, none of these options are available; Japanese firms produce within the EU and EU enlargement rules out the large-scale use of guest workers focusing reform on change management, work reorganisation and, even more so, workplace industrial relations.

Just how workplace reform is to be achieved was revealed in February this year. Cost cutting and component part outsourcing are precluded by guaranteed contracts that run until at least 2008; this, combined with a 2004 no compulsory redundancy agreement that runs until 2011, forced the company back to an early-retirement programme. Designed to reduce VW's German labour force of 103,000 workers by 30,000 , the details of the deal not only reflect but also reinforce the so-called 'VW law' that protects the integrity of German firms and in this case its exceptional pattern of industrial relations. To qualify for retirement at 59 years, workers must be 55 years old by 2009 and will receive a full salary until they are 62 years old when they receive their pension; 20 per cent of the pay package remains underwritten by government subsidies.

The significance of the VW case lies in what it tells us about the German business and industrial relations system. The current crisis is apparently similar in scale and scope to that experienced in the early 1970 s when both the business system and the industrial relations system were able to negotiate a pathway through the crisis. This pathway marked the development of diversified quality production to further embed 
stakeholder approaches to corporate governance and industrial relations in the German business system. In the contemporary period, the question raised by the VW crisis is threefold. First, if VW can negotiate a way through, does this suggest that the stakeholder approach to business and the Rhineland model of industrial relations are more resilient than advocates of Anglo-American approaches suggest? Second, does the change package at VW illustrate that codetermination and stakeholder approaches can incorporate the requirements of shareholder capitalism to usher in an enlightened model of shareholder capitalism into the German economy? Third, and related, will this preclude the arrival of and necessity for Anglo-American management techniques in German-based firms? In short, does the VW case suggest change, continuity or pathway adjustment?

\section{STAKEHOLDER REFORM AND SHAREHOLDER CAPITALISM?}

Discussion of reform in German industrial relations is compounded by the fact that Europeanisation and the European project within which Germany was central has now diverged away from its postwar origins in the Marshall Plan, the Treaty of Rome and the Single European Act.

The way we look at things is greatly influenced by the models and embedded approaches that prevail within national business systems. Reform of the German business system can only go towards shareholder capitalism, but at the same time this movement is significantly influenced by Germany's postwar stakeholder legacy.

\section{The diffusion of shareholder capitalism}

Following the demise of Fordist approaches to volume production and the international diffusion of Japanese methods in the 1980s, a new growth regime premised on the virtues of enhancing shareholder value (SHV) became influential during the 1990s. Shareholder capitalism refers to a phenomenon where American and British firms are now seen to make dramatic and swift changes to their core strategies and associated growth regimes in order to emphasise the priorities of outside investors precisely because financial institutions, institutional investors and private equity firms in particular are able to exert a strong influence over management action, if not managerial performance. Theoretically, if shareholder capitalism and shareholder value represent a restatement of profit maximisation, shareholder capitalism and SHV should drive allocative and organisational efficiency further forwards. However, empirically, where national business systems are increasingly supported by the market, the imperative of shareholder value may witness the focus of corporate performance moving beyond measures such as productivity, good working conditions and a balance between social justice in the workplace and profitability.

The emergence of $\mathrm{SHV}$ as a driver for management practice can be traced to the crisis of American capitalism in the early 1980s. The recovery from the collapse of profits in the late $1970 \mathrm{~s}$ and the aftermath of the Iranian oil shock of the early 1980s led American economists and management theorists to argue that stalled economic growth and declining productivity were not temporary but apparently permanent shocks to the American business system (Hutton, 2002: 124). Economists and management theorists began to question and subsequently reject much of the theoretical and institutional underpinnings of postwar economic success in the American 
business system. Economists rejected the utility of managerial theories of the firm that emphasised managerial discretion and shareholder deference to professional salaried managers (Bearle and Means, 1932; Chandler, 1977; Williamson, 1964; 1967). Emphasising instead relatively new agency theories (Alchian and Demsetz, 1972; Jensen and Meckling, 1976) and transaction cost theories (Williamson, 1975), economists and management theorists were joined by institutional investors and consultants who began to focus not on the efficiency and organisational capability in American and British variants of managerial capitalism, but on its waste and inefficiency. Academic debate over corporate governance in the American and British business systems now appears resolved in favour of shareholder capitalism wherein shareholders hold ultimate control of the firm with management (their agents), fulfilling their obligations under company law by explicitly managing in the interests of the shareholding class to the exclusion of other stakeholders (see Hansmann and Kraakman, 2001, where this view is elaborated). Similarly, Rappaport (1998) argues that the creation of economic value for shareholders is the sole success criterion for corporate strategy. Moreover, policy-wise this view is echoed in recent pronouncements by the OECD that explicitly recognises the primacy of shareholder interests (OECD, 2004).

The concentration on returns to shareholders disregards other stakeholders, in particular workers and organised labour, to the extent that owner interests and those of senior management and employees are assumed to be the same. Intuitively managing for SHV is a threat to labour, particularly the often cited association between SHV, downsizing and boosts to managerial remuneration. However, beyond the AngloAmerican paradigm, managing for shareholder value in a stakeholder system such as the German one is not necessarily evident. For example, direct linkage between this development and movement to 'lower-road' approaches to industrial relations summarised as 'hire and fire', short-term contracts, less job security, poor training and the potential threat of outsourcing and offshoring may in fact be mediated by cultural and institutional values embedded within the German system.

An example of this is that, on the one hand, pro-business reform and the adoption of Anglo-American managerial practices for executives may strengthen the capability of German firms to stave off hostile overseas takeovers within a more internationalised market for corporate control. On the other hand, German firms have been adept in their use of external acquisitions on the financialisation model to satisfy the demands of institutional and family shareholders by deploying Anglo-American techniques liable to significant institutional and political opposition in the domestic economy. Indeed, the threat of financialisation and an internationalised market for corporate control appears as a lever by which German managers become more professionalised-less vocationally committed to a particular firm or sector-and lobby for the reform of their own remuneration packages on the Anglo-American model (see Carr, 2005). So while the market for corporate control and actors therein is diffused across the German business system to generalise the operational rhetoric of short-termism, it is less clear that this will lead to the diffusion of lower-road approaches to industrial relations. In large measure this is the case because, in contrast to the UK, where a focus on short-term profitability is the central index of business performance, in Germany a higher level of institutional regulation has made it difficult for employers to treat labour simply as a disposable commodity. Collective bargaining, codetermination and state legislation have resulted in high wages and restrictions on employers' freedom to dismiss workers. This means that employers have had to achieve competitiveness by ensuring that high wages are matched by high productivity and by com- 
peting on the basis of product quality rather than price. This has meant placing a relatively high emphasis on skill in the workforce and the production process.

\section{The national embeddedness of stakeholder capitalism?}

Within the German business system, firms operate a stakeholder model of corporate and organisational governance wherein management obligation is not only or even primarily to shareholders but to the various needs of a range of stakeholders in the company, including employees and, in larger firms, organised labour. This approach to employment regulation is historically embedded and represents an integral part of the German business system and its approach to organising and regulating economic activity. Re-established during the allied occupation after the Second World War, Germany's system of industrial relations contains a central principle of collective selfregulation by employer and employee organisations within a Constitutional framework of law and includes the following key characteristics. First, German employment law establishes basic principles and institutional arrangements that allow employers and workers to regulate their own affairs with little direct interference from the state. More significantly, and more controversially as the VW case demonstrates for the contemporary period, the law also provides for workers to be represented on the supervisory boards of firms employing more than 500 employees. Second, and related, German employment law makes important distinctions between collective bargaining and codetermination in terms of their functions, institutions and the levels at which they operate. Collective bargaining establishes basic terms of employment such as wages and hours; in contrast to this, codetermination deals with issues that arise from the application of industry-wide collective agreements in individual enterprises.

Traditionally, collective bargaining takes place at industry or sector level within Germany's 25 Lande or local states, whereas codetermination is conducted between works councils and management at workplace level. However, since the mid-1980s, the role of works councils in negotiating terms and conditions of employment has increased owing to the decentralising tendencies in German industrial relations and the preferences of some overseas multinational firms for workplace bargaining. More recently, there has been growing criticism of key features of the German employment system from many economic policy advisers and financial and business interests seeing it as a hindrance to renewed economic growth, competitiveness and job creation. Citing economic stagnation and unemployment over the last 10 years, these interests became increasingly critical of aspects of the employment system in general, particularly the level of employment protection and social welfare benefits for workers and the centralised system of collective bargaining. These criticisms have developed into demands for reforms to increase labour market flexibility (for more detailed discussion of the German system and its present difficulties, see Claydon and Clark, 2006; Frick and Lehmann, 2005; Jacobi et al., 1998).

The criticism of centralised collective bargaining is that it sets too high a minimum wage, which together with the social welfare system prevents wages for unskilled workers adjusting to a level that would lead to more job creation. It is also argued that it prevents enterprises from addressing the need to develop more flexible ways of using labour in order to raise productivity and reduce costs. The reforms that have been demanded are that restrictions on the use of flexible forms of employment such as temporary and fixed-term employment should be eased; the level of social benefits should be cut back to ease the tax burden on employers and enable wages to be more 
flexible at the lower end of the market; and collective bargaining should be decentralised to allow for greater wage flexibility and permit negotiation of company workplace 'pacts' on specific issues. However, as the VW case demonstrates, this is difficult to negotiate and much of Chancellor Merkel's political rhetoric during last year's election campaign has been reined in and significantly moderated.

Pressures for labour market reforms along Anglo-American lines have been reinforced by the growing influence of the principles of shareholder capitalism and managing for shareholder value in the German business system. The diffusion of multinational firms, the spread of institutional investors and private equity firms and the demands for greater financial transparency have led some analysts to build on the seminal contribution of O'Sullivan (2000) to argue that strong pressures are developing to force Germany to converge towards the Anglo-American model of corporate governance based on shareholder capitalism (see Gulger et al., 2004). Given the incompatibility of shareholder value with the existing stakeholder principle, its diffusion among German companies could lead to the eventual abandonment of the German employment system and convergence towards a more hybrid mode (see Pudelko, 2005).

\section{Is reform of the German business system inevitable?}

The answer lies in two words: accession and globalisation. For many years, the German business system sustained competitive advantage in quality-diversified production. Therein the components of the German business system-skilled labour, management concerned with innovation and technological development, integrative and orderly labour relations, and long-term finance provided by local banks-combined to produce value added, that is, cost plus products and services. The fall of the Berlin Wall witnessed the beginning of the end. Saddled with major problems within the economy, Chancellor Kohl levied a unification tax, which is still in place, and launched a massive programme of public works to modernise the infrastructure of eastern Germany. Later in the 1990s, the German business system came under AngloAmerican pressures as new managerial techniques, summarised as performance management and variable pay combined with new managerial objectives focusing on shareholder value, exposed the weaknesses of the German business system (O'Sullivan, 2000). British, and more particularly American, multinationals located in Germany appeared to be more efficient than many of their German counterparts, not because they necessarily were, but because they competed on the basis of shareholder capitalism not stakeholder capitalism, the characteristic, widely accepted feature of postwar West Germany. German subsidiaries of American and British multinationals proved to be effective mechanisms for the diffusion of new managerial techniques for human resource management, performance management and variable pay for management grade employees, innovations that became increasingly attractive to indigenous firms in the early 21 st century (Carr, 2005; Kurdlebusch, 2002).

\section{THE INDUSTRIAL RELATIONS IMPLICATIONS OF DIVERGENT RESPONSES TO PRESSURE FOR REFORM}

For the German business system, coming to terms with the increasing internationalisation of the Anglo-American model of corporate governance involves the diffusion of several interrelated pressures for change. First, shareholder capitalism on the 
Anglo-American model requires standard financial reporting in order to garner the support of capital markets. Second, and directly related, the support of capital markets and central actors, such as pension funds and private equity firms, see merger and acquisition activity as a source of growth and shareholder value that may eclipse longer-term organic growth and development. Third, shareholder capitalism broadly defined has implications for organisational structures and patterns of performance management wherein cost plus models of corporate strategy and related human resources/industral relations strategies come under significant cost-reduction pressures. For example, DaimlerChrysler recently announced a $€ 1$ billion cost-cutting programme that includes $6,000 \mathrm{HQ}$ redundancies and a 'trading-down' relocation of its HQ from the centre of Stuttgart to a less expensive suburb. What remains unclear is whether the $€ 1$ billion will be reinvested in product development and engineering or returned to shareholders.

The VW case also indicates that shareholder value pressures cannot be easily accommodated where legislative safeguards over industrial relations prevail. Angela Merkel, during the election campaign, suggested that two-thirds support from the workforce should allow employers to bypass works council decisions. However, failure to secure majority support from the electorate saw this suggestion shelved. Equally, the comparatively insular pattern of corporate governance enjoyed by German firms, and VW in particular, means that a focus on shareholder interests is unlikely in the foreseeable future. Examining German industrial relations through the lens of shifting coalitions within capital, management and labour reveals that although foreign investors bring with them pressure for shareholder value, reflecting globalisation, these actors display divergent responses to these pressures which can be summarised under three headings.

\section{Towards enlightened shareholder value: codetermination and stakeholder corporate governance?}

Adapting to the demands of globalisation may mean just that-pathway adjustment to incorporate a new pressure rather than a more forceful change to a new orientation. As a paradigm example, the case of VW demonstrates that the emergence of shareholder value strategies for capital and management has not undermined codetermination and collective bargaining as core institutions in the German business system. However, as Jackson (2003) persuasively argues, although both are underpinned by legislative fiat in the contemporary period, each may become subject to contractual modification. Contractual modification describes the process of decentralisation in German industrial relations whereby sector-wide collective bargaining agreements are increasingly subject to 'opening clauses' that entertain plant-level negotiation over issues traditionally dealt with more centrally (Hassel, 1999). This is not a recent phenomenon. Opening clauses have also morphed into employment pacts that promote pay concessions or changes to working time as responses to lacklustre consumer demand and poor financial performance (Seifert and Massa-Wirth, 2005).

Competitive and financial pressures can therefore be mediated within existing institutional arrangements wherein the stakeholder dimension enables existing arrangements to incorporate new developments. Hence, there is little evidence to show that firms who are ushering in shareholder value seek to discontinue codetermination (Jackson et al., 2005: 115-118). Furthermore, longitudinal studies demonstrate that adoption of Anglo-American management styles and an increasing orientation 
towards shareholder value are more consistently found in German firms that are internationalising, whereas domestic and family-owned firms conform to more established institutional and cultural determinants of management behaviour (Carr, 2005). These differences are significant because while they demonstrate pathway adjustment in German firms they also indicate that the embeddedness of component parts of the industrial relations system continue to provide some protection for workers against emergent pressures. Pressures for system convergence (and below this, at firm level, pressures for standardisation in production) are evident in sectors where German firms compete with firms that originate in other nations. However, codetermination and collective bargaining provide management in these firms with sufficient space for strategic choice to protect not only themselves but also workers from some of the centralising tendencies of multinational firms (Geppart et al., 2003; Williams and Geppart, 2006).

This embracing of new developments is a sign of strength in a system and the adoption of a microeconomic approach to wages and working time suggests that collective bargaining and codetermination are becoming a basis for differentiated company-level negotiations. Opening clauses and opt-out agreements provide an alternative to Merkel's rhetoric of labour market deregulation and reduced trade union power and suggest that the Rhineland model continues to provide for social cohesion wherein established stakeholders support the development of enlightened shareholder value.

\section{Continuity and conservatism: the predominance of embedded stakeholder traditions?}

While on the one hand the literature suggests an embedded system experiencing pathway adjustment, another strand to the literature eschews this in favour of a more path-dependent course that stresses the imperative of social cohesion. Since 1945, codetermination and collective bargaining have during the period made a significant contribution to coupling German corporate success with a period of sustained political stability helping to prevent both revolutionary tendencies in the workforce and fascist attitudes among the business class. A significant danger of decoupling economic and, more significantly, financial success from measures to maintain political and institutional stability is that the process may undermine social cohesion, an endemic feature of German society since 1945. The emergence of a shareholder value dimension within German firms and foreign multinationals could set this process in motion and on this basis accommodative measures, such as opt-out clauses, workingtime pacts or the acceptance of company-level bargaining within multinationals, need to be resisted by trade unions, which are one of the key actors committed to domestic cohesion in the German business system (Fiss and Zacac, 2004). Trade unions do not have to accept their decline or the need for structural accommodation on a social partnership model but, alternatively, can shape their own environment and future by continuing to promote embedded protection and representation strategies as part of their renewal (Annesley, 2006; Frege and Kelly, 2003).

Frege (2005) addresses this point head-on by arguing that despite growing internationalisation, industrial relations research remains embedded in national research traditions. This argument is not just academic; research on convergent industrial relations practices in America, Britain and Germany does not demonstrate a convergence of practice within the three countries. In the main, this is the case because of the different state traditions in each country. Thus, in Germany the presence of the 
state and workplace democracy remains a dominant issue for research because of its embedded presence. So while shareholder capitalism and associated organisational design-making and institutional control strategies may represent international best practice, institutional actors within the German business system can use them as an opportunity to forge renewal strategies. Similarly, German multinationals are characterised as permissive in relation to established approaches to industrial relations because of this embeddedness. However, this permissiveness is less evident in subsidiary operations in more accommodating economies beyond Germany (Geppart et al., 2003; Geppart and Williams, 2006).

\section{Outside in: shareholder value as a change management driver?}

Much of the literature on subsidiary operations in multinational firms examines the degree to which local managers can use their position to wrestle concessions from the centre, sometimes referred to as a host country effect (Ferner et al., 2004; Williams and Geppart, 2006). At the same time, there is some evidence that, at least within some strands of German management, shareholder value principles are taking hold (Carr, 2005). The difference of opinion in the literature raises the question as to whether German managers will continue to operate within the established framework of the German business system or begin to increasingly initiate choices to change the system. Thus, if a hybrid shareholder-stakeholder system is emerging, the tension that it is likely to create within the management class is not yet evident.

Initially associated with the diffusion of foreign, in the main American, multinationals' performance, management techniques (in particular the adoption of variable pay) demonstrate the degree to which German firms are adopting a shareholder orientation. In addition, measures such as variable pay are also a proxy for the degree to which German firms compete in more global markets. Comparative studies demonstrate how the adoption of these measures, among many others, illustrates that to compete globally German firms must operate on the same performance and shortterm principles as American and British firms (Carr, 2005; Gulger et al., 2004). Kurdlebusch (2002) argues that while this is the case, works councils and trade unions remain centrally involved in the process demonstrating the embeddedness of multinational firms within the German business system. However, earlier contributions argue that Anglo-American management techniques associated with short-termism and the related increases in central control may threaten the established institutional framework (Lane, 2000; 2001; O’Sullivan, 2000).

More recent survey and case-study material suggests that the diffusion of shareholder-value approaches in German management does have the potential to decouple management remuneration and objectives from the more embedded collectivist stakeholder tradition. For example, while adopting the rhetoric of shareholder value management may fail to implement strategies that are associated with it and may in more extreme cases actively lobby against the diffusion of such approaches (Fiss and Zacac, 2004; Williams and Geppart, 2006). However, in low-skilled sectors which are more internationalised and dominated by American firms, German managers may be less able to resist such tendencies, via, for example, the use of coercive comparisons (Royle, 2004). Despite this, evidence reform of financial compliance and transparency regulations for Germany's largest firms and increased foreign share ownership are likely to see German management increasingly rewarded with stock options, performance and profit-related bonus schemes. While this trend is in motion, it may also be 
influential in garnering the support of senior executives for three-year executive contracts rather than five-year contracts currently preferred by German firms. Similarly, performance management is clearly present, if unresearched, in the Mittlestand sector and its further diffusion to large firms would witness the system becoming more shorttermist and open up the possibility that management would choose to operate differently. Management careers may become more professionally and less vocationally driven on the established model in the American and British business systems.

Overall, the literature suggests a variety of responses to emergent pressures associated with shareholder value approaches and imperatives. For German firms, structural reforms to financial reporting and associated measures of competitiveness have ushered in the imperative of securing the support of capital market actors, particularly as management internationalise the operations of a firm. However, the emergence of management practices has been associated with managing for shareholder value (performance management metrics, stock options and concentration on share price as an index of competitiveness); although it has weakened support for collective bargaining, it has done so in a manner that is indicative of its embeddedness within the German business system.

Within a legally regulated system of industrial relations, market dynamics, established patterns of state regulation and the coverage of collective bargaining are, as institutions, interwoven within the business system. So the emergence of shareholder dynamics, pressures for workplace reform and flexibility in collective bargaining have to engage with the framework of the statutory rules. Equally, within collective bargaining while the system remains sector-driven in terms of coverage, the negotiation of opening clauses and opt-out pacts may witness further decentralisation of the system. In respect of codetermination, the position is more fluid: 18 of Germany's 25 Lande have codetermination agreements in place wherein employee representatives hold a third of the seats on company supervisory boards for large firms. While 60 per cent of German workers are not covered by the provisions of codetermination, trade unions see it as an essential component in dispute resolution whereas managers often see codetermination (as at VW) impeding flexibility and change management (Claydon and Clark, 2006). A currently convened business trade union commission is expected to call for a reduction in the number of seats on company supervisory boards; however, there has been no discussion of any alteration in the distribution of the seats (Williamson, 2006). The important point is that if collective bargaining is decentralised, more issues may devolve from national-level bargaining to firm-level negotiation under the auspices of the works council. The interesting research question raised by this possibility centres on the status of collective bargaining as emergent framework agreements are developed at workplace level.

\section{CONCLUSION}

As strong supporters of the European project, German politicians and the vast majority of its business class have been at the forefront of four economic, institutional and social developments designed to further enhance European unity. First, a pan-union single currency, the euro, was introduced in January 2002 (in Germany's case without popular endorsement in a referendum). Second, the related European Central Bank assumed responsibility for the euro, but more particularly management of a eurozone-wide monetary policy was specifically designed to combat potential 
inflationary pressures. Third, and again directly related to the two previous points, a eurozone-wide Stability and Growth Pact for fiscal and taxation prudence was designed to compel 'less disciplined' Member States (Greece, Italy and Portugal were often highlighted) to control public sector deficits at 3 per cent of annual national income. Last, an EU-wide political constitution that is beyond and including nonEuroland states to secure improved decision making in the Commission and European Parliament.

The pace at which events have overtaken German enthusiasm for these components of Europeanisation is remarkable and, if predicted five years ago, would have been widely discounted. The transition from Deutschmark to euro was forecast to lead to some frictional inflationary pressures which have turned out to be more structural in form as fresh food and many other consumer items have increased significantly in price. Second, the strictures of the European Central Bank based in Frankfurt have turned out to be both an economic and a political embarrassment to Germany and France, each of whom has consistently breached Stability and Growth Pact controls over deficit financing. Neither France nor Germany has implemented the necessary deflationary courses required to eliminate excessive deficit spending to the extent that the requirement to control deficits appears de facto as merely a guideline. Third, the rejection of the EU's political constitution by France and Holland has raised serious political questions in Germany's business class, the trade union movement and the population at large about the loss of stock value, the value of incomes and the value of accumulated savings that has resulted from the transition to the euro and associated fiscal and monetary centralisation.

More specifically, in respect of industrial relations reform and reform of managerial practices in Germany, the failure of centralised monetary policy and the manner in which fiscal policy is neutralised by the Stability and Growth Pact has led to two unsavoury but apparently effective constraints. First, a single currency-fixed exchange rate system rules out any form of managed float or competitive devaluation to stimulate economic activity. Second, income taxation policy has in effect become centralised and therefore in large measure is unavailable to either boost reflation or control inflation, and in Germany's case is comparatively high in the first place because of the unification tax. To choke off inflationary pressures associated with rising oil prices, Merkel has hinted that it may be necessary to increase value-added tax rates.

Industrial relations reform and reform of managerial practices can be seen as necessary because each of the constraints described above forces the burden of economic adjustment back onto the domestic economy and its institutional regulation. Labour market flexibility in the form of more decentralised collective bargaining and reform of codetermination rules appear as central mechanisms for adjustment. The problem is compounded by the fact that Germany remains a powerhouse in manufactured goods, many of which are exported, accounting for 40 per cent of Germany's GDP, directly providing 9 million jobs. So while corporate profits are booming in export sectors, workers within Germany are still being asked via opening clauses and employment for competitiveness pacts to display flexibility on the Anglo-American model. As outlined earlier, the obvious danger here is one of decoupling of social cohesion between the successes of corporate Germany and the broader German economy and its domestic regulation.

Eurozone countries set monetary policy jointly via the European Central Bank and this in turn dictates the parameters of fiscal policy; yet policies on wages and working conditions are determined nationally. German firms have sought to restore national 
competitiveness through the moderation of wage increases and greater worker flexibility. In combination, these policies have not necessarily improved or restored national competitiveness, but they have set two developments in train. First, the effect of German wage moderation and workplace reform is competitive, creating similar pressures in other EU nations, especially in eurozone countries, a form of competitive adjustment reminiscent of competitive devaluations in the 1930s. Second, many German multinational firms are looking beyond the EU for markets and production facilities. For example, EADS, the Franco-German aerospace group, has developed a 'southern strategy' in order to win contracts from the US defence department. Therein the promise of significant investment in high unemployment, low job states such as Alabama, gains political leverage locally and brings with it significant economic benefits in lower, non-union, labour costs. Each of these developments is likely to reinforce the pressures for domestic adjustment in the labour market, sometimes termed competitive governance arrangements (Sisson, 2006: 46).

The VW case suggests that the German business system, and within that its pattern of industrial relations, has a strong imperative towards reform. However, the institutional framework of German industrial relations is so embedded that the movement to Anglo-American shareholder capitalism, although in process, is evidently moving towards a hybrid pattern of enlightened shareholder value. Beyond this general conclusion, there are four further caveats which merit discussion. First, while the dominant trend within industrial capitalism is one of gradual deregulation from coordinated market activity towards more liberally coordinated activity, clear convergence on the Anglo-American model of shareholder capitalism is not in evidence. The familiar headline statements that status-based and resource-endowed employment is undermined in favour of lower-road agency approaches to employment regulation are not in evidence in the German system. Second, and directly related, the presence of constitutionally framed legal norms combined with institutionally embedded cultural and social norms deflect and obstruct the unfettered diffusion of shareholder capitalism in Germany. In an era when more measured historical evaluation has been abandoned in favour of terms like 'embeddedness', it is sobering to recognise both theoretically and empirically how the past evolution of a business system influences its future development, suggesting that discussions of shareholder capitalism or stakeholder capitalism are themselves limited and determinist. Third, in relation to the German business system and its attendant system of industrial relations, the impact of labour rights and organised labour on labour management do exercise some influence over capital and management in a manner that is absent in the UK or the USA where the absence of institutionally and socially legitimate legally enforceable participation has confined criticism of shareholder capitalism to activist and ethical investors or companies seeking some measure of corporate business responsibility. Last, the competitive governance arrangements referred to previously represent German reaction to intraEU developments which are not the same as the emergence of shareholder capitalism or resistance to it. Hence, as a review of the literature in part two demonstrates either enthusiastically or reluctantly, a country-specific variant of enlightened relational shareholder capitalism is emerging in the German business system.

\section{References}

Alchian, A. and H. Demsetz (1972), 'Production, Information Costs and Economic Organization', American Economic Review, 62, 777-795. 
Annesley, C. (2006), 'Ver.di and Trade Union Revitalisation in Germany', Industrial Relations Journal, 27, 2, 164-180.

Bardou, J. P., J. Chanaron, P. Fridenson and J. Laux (1982), The Automobile Revolution: The Impact of an Industry (Chapel Hill, University of North Carolina Press).

Bearle, A. and G. Means (1932), The Modern Corporation and Private Property (New York, Macmillan).

Carr, C. (2005), 'Are German, Japanese and Anglo-Saxon Strategic Decision Styles Still Divergent in the Context of Globalisation?', Journal of Management Studies, 42, 6, 1155-1188.

Chandler, A. (1977), The Visible Hand: The Managerial Revolution in American Business (Cambridge, Cambridge University Press).

Claydon, T. and I. Clark (2006), 'Comparative HRM', in J. Beardwell and T. Claydon (eds), Human Resource Management: A Contemporary Perspective, 5th edn (London, Prentice Hall Chapter 15.

Ferner, A., P. Almond, I. Clark, T. Colling, T. Edwards, L. Holden and M. Muller (2004), 'The Dynamics of Central Control and Subsidiary Autonomy in the Management of Human Resources: Case Study Evidence from US Multinationals in the UK', Organization Studies, 25, 3, 363-393.

Fiss, P. and E. Zacac (2004), 'The Diffusion of Ideas over Contested Terrain: The (Non) Adoption of Shareholder Value Orientation Among German Firms', Administrative Science Quarterly, 49, 4, 501-572.

Frege, C. (2005), 'Varieties of Industrial Relations Research: Take-over, Convergence or Divergence', British Journal of Industrial Relations, 43, 2, 179-207.

Frege, C. and J. Kelly (2003), 'Union Revitalisation Strategies in Comparative Perspective', European Journal of Industrial Relations, 9, 1, 7-24.

Frick, E. and E. Lehmann (2005), 'Corporate Governance in Germany: Ownership, Codetermination and Firm Performance in a Stakeholder Economy', in H. Gospel and A. Pendelton (eds), Corporate Governance and Labour Management: An International Comparison (Oxford, Oxford University Press) pp. 122-148.

Geppart, M. and K. Williams (2006), 'Global, National and Local Practices in Multinational Corporations: Towards a Socio-political Framework', International Journal of Human Resource Management, 17, 1, 49-69.

Geppart, M., K. Williams and D. Matten (2003), 'The Social Construction of Contextual Rationalities in MNCs: An Anglo-German Comparison of Subsidiary Choice', Journal of Management Studies, 40, 3, 617-641.

Gulger, K., D. Mueller and B. Yurtoglu (2004), 'Corporate Governance and Globalisation', Oxford Journal of Economic Policy, 20, 1, 129-156.

Hansmann, H. and R. Kraakman (2001), 'The End of History for Corporate Law', Georgetown Law Journal, 439, 439-441.

Hassel, A. (1999), 'The Erosion of the German System of Industrial Relations', British Journal of Industrial Relations, 37, 3, 483-505.

Hutton, W. (2002), The World We're In (London, Little, Brown).

Jackson, G. (2003), 'Corporate Governance in Germany and Japan Liberalisation Pressures and Responses', in K. Yamamura and W. Streeck (eds), The End of Diversity? Prospects for German and Japanese Capitalism (Ithaca, NY, Cornell University Press).

Jackson, G., M. Hopner and A. Kurdlebusch (2005), 'Corporate Governance and Employees in Germany: Ownership, Co-determination and Firm Performance in a Stakeholder Economy', in H. Gospel and A. Pendleton (eds), Corporate Governance and Labour Management: An International Comparison (Oxford, Oxford University Press).

Jacobi, O., B. Keller and W. Muller-Jentsch (1998), 'Germany Facing New Challenges', in A. Ferner and R. Hyman (eds), Changing Industrial Relations in Europe, 2nd edn (Oxford, Blackwell) pp. 218-270.

Jensen, M. and W. Meckling (1976), 'Theory of the Firm: Managerial Behaviour, Agency Costs and Ownership Structure', Journal of Financial Economics, 3, 4, 305-360. 
Kurdlebusch, A. (2002), 'Multinationals and the Rise of Variable Pay in Germany', European Journal of Industrial Relations, 8, 3, 325-349.

Lane, C. (2000), 'Globalisation and the German Model of Capitalism-Erosion or Survival?', British Journal of Sociology, 5, 2, 207-234.

Lane, C. (2001), 'The Emergence of German Transnational Companies: A Theoretical Analysis and Empirical Study of the Globalization Process', in G. Morgan, P. Kristensen and R. Whitley (eds), The Multinational Firm: Organizing Across Institutional and National Divides (Oxford, Oxford University Press).

Milne, R. (2006), 'VW Pension Deal Paves the Way for Huge Job Cuts', Financial Times, 6 February, 25.

OECD (2004), Principles of Corporate Governance (Paris, OECD).

O'Sullivan, M. (2000) Contests for Corporate Control: Corporate Governance and Economic Performance in the United States and Germany (Oxford, Oxford University Press).

Pudelko, M. (2005), 'Cross-national Learning from Best Practice in the ConvergenceDivergence Debate in HRM', International Journal of Human Resource Management, 16, 11 , 2045-2074.

Rappaport, A. (1998), Creating Shareholder Value: A Guide to Managers and Investors, Revised edition of the 1986 original (New York, The Free Press).

Royle, T. (2004), 'Employment Practices of Multinationals in the Spanish and German QuickFood Sectors: Low Road Convergence?', European Journal of Industrial Relations, 10, 1, 51-71.

Seifert, H. and H. Massa-Wirth (2005), 'Pacts for Employment and Competitiveness in Germany', Industrial Relations Journal, 36, 3, 217-240.

Sisson, K. (2006), 'Personnel Management and European Integration: A Case of Indelible Imprint?', in S. Bach (ed.), Managing Human Resources (Oxford, Blackwell).

Streeck, W. (1984), Industrial Relations in West Germany: A Case Study of the Car Industry (New York, St. Martin's Press).

Streeck, W. (1989), 'Successful Adjustment in Turbulent Markets: Automobile Industry', in P. Kristensen (ed.), Industry and Politics in West Germany (Ithaca, NY, Cornell University Press).

Williams, K. and M. Geppart (2006), 'The German Model of Employee Relations on Trial: Negotiated and Unilaterally Imposed Change in Multinational Corporations', Industrial Relations Journal, 37, 1, 48-64.

Williamson, H. (2006), 'Merkel Demands Workplace Reforms', Financial Times, 25 May, 6. Williamson, O. (1964), The Economics of Discretionary Behavior: Managerial Objectives in a Theory of the Firm (Englewood Cliffs, NJ, Prentice Hall).

Williamson, O. (1967), 'Hierarchical Control and Optimum Firm Size', Journal of Political Economy, 75, 123-138.

Williamson, O. (1975), Markets and Hierarchies: Analysis and Anti-trust Implications (New York, The Free Press). 